\title{
New Trends in International Direct Investment after the 2008 Economic
}

\section{Crisis}

\author{
Zhang Jin \\ Wuhan Institute of Design and Sciences, Wuhan City, Hubei Province, 430205 \\ 346591653@163.com
}

Keywords: international direct investment; trend; influence; enlightenment

\begin{abstract}
The 2008 world economic crisis has had an important impact on the global economy and the trend of international direct investment has changed significantly. The main changes are mainly manifested in three aspects: First, emerging market countries will accelerate foreign direct investment; Second, resources and market orientation will become increasingly prominent; High tech industry and modern service industry will become the focus of FDI. After analyzing the development trend, this paper studies the impact of these new trends on China's economy. Finally, it discusses the implications of these trends for China to attract international direct investment.
\end{abstract}

\section{New Trends in International Direct Investment}

Emerging market countries will accelerate foreign direct investment. With the advantages of small scale technology and technology localization, foreign investment in developing countries can expand the overseas market, reduce production costs and achieve industrial upgrading and technological innovation. According to Denning's theory of investment development stage, with the improvement of economic development level, its net foreign investment will gradually increase, and the capital importing country will become a capital exporting country in the end. In recent years, the emerging market countries, as such China, India has taken the pace of outward direct investment. With the development of economic level, the increase of trade surplus and the surge of foreign exchange reserves, emerging market countries are bound to expand the scale of foreign direct investment and integrate the industry value chain in the world. At present, the financial crisis hit the economy of developed countries, resulting in Western Multi-National Corporation self adjustment, for Multi-National Corporation in emerging market countries, it is a good opportunity to acquire to cheap quality assets and expand market share.

Take China as an example, according to the Ministry of Commerce statistics, in 2008, despite the impact of the financial tsunami, China's non-financial foreign direct investment is still up to $\$$, which means that China's role in the world economy is changing from the "product producer" to "capital exporter".

Resources and market orientation will become increasingly prominent. Due to the irreplaceable and non renewable of resources, resource factors have become increasingly prominent in the economic development and the occurrence and control of resource elements will become an important symbol of the comprehensive national strength of a country and region. At present, various countries launched fierce competition around the resources, the world economy has entered the era of resource economy. Performance in the field of international direct investment, both developed and emerging market countries, resource oriented FDI will become the main form of 
foreign direct investment of Multi-National Corporation.

On the other hand, the expansion of market size led the deepening of labor division, the international division of labor is the main driving force of economic growth in the world. However, even if the globalization and commodity can free flow, for the protection of their own industries and stable employment, trade barriers are still common in all countries. Especially since the financial crisis, in order to reduce the unemployment rate and increase domestic demand, governments have taken trade protection measures. As a result, through the international direct investment, they can effectively bypass various trade barriers. Occupying and expanding the target market will be primary means for all countries deal with trade protectionism and expand external demand.

High tech industry and modern service industry will become the focus of FDI. As the product life cycle is shortened, the traditional industry cycle theory has not been applied, multi-National Corporation tend to produce and sell new products in the global synchronization. The traditional theory of marginal industry transfer will be out of date, so the industrial distribution of FDI will be in line with the law of industrial development. The law of modern industrial development presents two characteristics: First, the promotion of traditional industries for the economic development decreases day by day, the development of high and new technology is fast and tends to give birth to a new industrial revolution; Second, the deepening of international division for labor and the promotion of specialized production to the world economy is becoming more and more significant, continuous refinement of the labor division within the industry will be the trend of the development of modern industry. In recent years, developed countries have completed the transfer of traditional industries to developing countries. While the developed countries focus on resource to develop high-tech industry and modern service industry. On one hand, under the shadow of the financial crisis, the global economy is short of new economic growth point, in order to get out of the crisis, to ensure the status of global leadership, developed countries led by the United States is bound to further increase the global allocation of resources to promote the development of new energy, new materials and other high-tech industries, and high-tech industries will become the main field of international direct investment; On the other hand, in order to give full play to the specialization role in economies scale, cost reduction, technological innovation and other aspects, multi-National Corporation tends to transfer the non core business outsourcing to specialized contractors, so they can concentrate on core business to enhance its competitiveness, this is particularly true when the financial crisis is spreading.

UNCTAD report pointed out that machinery and equipment, information and communication technology, energy, chemical and plastics, life sciences, health and convenience food industry, transportation equipment, business services, personal services and environmental protection will likely become a hot spot in the future of international investment, the combination of technology innovation, market growth and organizational change may lead to the rapid growth of FDI flow. In addition, UNCTAD investigation for the global number of multi-National Corporation shows 27\% of the company's sample in service sector says they will strive to increase its investment in the next 2 years, in particular, telecommunications, transportation, water and electricity and other infrastructure areas.

\section{The Impact of the New Trends on China's Economy}

The number of foreign capital utilization will decrease, but the quality is expected to improve. Affected by the financial crisis, the pace of international capital into China has slowed down significantly. In the context of the global real economy suffered a heavy blow and the financial crisis is still not clear, the situation attracting foreign investment is not optimistic. Due to the 
financial crisis had a relatively small impact on China, so domestic demand remains strong. The business of national Corporation in China has become the only bright spot in its global operations, for China's recovery prospects and market potential, many Multi-National Corporation begin to adjust its global strategic deployment. They increase the scale of investment projects, at the same time, the quality has improved. For example, in 2008, Nestle group has strategically expanded its milk base in China, invested and constructed new dairy products factory in Eergu'Na, Inner Mongolia, established the second R \& D centers in China. Due to the good performance of the subsidiary in china, SIEMENS will further strengthen innovation in China and increase investment in China's rural areas suitable for technology and solutions in order to maintain a rapid growth momentum of the business. Bayer will continue to increase investment in China, including the establishment of R \& D organizations, to further expand its R \& D activities in China.

Overseas investment opportunities are more, but the risk is huge. Financial tsunami undoubtedly brought opportunities for Chinese enterprises to accelerate the pace of internationalization, continuous "de-leveraging" process makes global enterprises faced with a serious shortage of liquidity, it is urgent to carry out financing through the equity, the sale of assets and other ways. On the other hand, from a global perspective, whether it is the resource commodity prices or physical asset prices, they all appeared to fall in varying degrees, which expands the pace for China's enterprises to provide an opportunity to go out. However, the global financial crisis has also brought many difficulties to the overseas investment of Chinese enterprises, such as external demand to fall, financial constraints etc. At the same time, the deepening of the crisis led to the corporate default rate and capital chain rupture, etc., which have brought unexpected risks to the enterprise. In particular, the current decline in demand, prices in the doldrums, corporate profitability is difficult to reach expectations. If the company headquarters injection capacity is not strong, the subsidiary will bear a heavy burden. Financial turmoil makes national economic policies tend to be conservative,such as South Korea, Vietnam and other countries have introduced a series of new measures for foreign exchange control. In order to strengthen financial supervision, some developed countries are introducing new accounting standards and risk assessment standards, its economic and financial regulation has also brought new uncertainties for Chinese enterprises "going out".

Service outsourcing market is large, but facing fierce competition. In recent years, international service outsourcing get $\mathrm{s}$ a rapid development and its field is widening, which has become an irreversible trend in the new round of global industrial transfer. At the same time, the international service outsourcing market share of high technology content will be more and more high and service outsourcing competition will become increasingly fierce, so China should make great efforts to develop international service outsourcing. However, the development of offshore outsourcing in China is still in its infancy, in the international outsourcing market, it accounted for less than $10 \%$ of the share, the further development is facing fierce competition from India, Ireland, Philippines and other countries. Currently, Australia and Canada are regarded as the most mature offshore BPO and ITO access market. Mexico undertakes most of the American market business, and Ireland, Russia is taking advantage of its geographical and linguistic advantages to undertake the EU's offshore outsourcing. As a result, the development of international service outsourcing in China is facing fierce competition.

\section{The Implications of the New Trends for China to Attract International Direct Investment}

The use of foreign capital can not only solve the problem of domestic resources, promote economic growth, but also learn and absorb advanced technology in developed countries, which can promote 
industrial upgrading. Therefore, attracting international direct investment is a long-term strategy. China is in a period of rapid economic growth, there is a huge market and relatively complete industrial system, continuing to carry out market economic reform, expand opening to the outside world, promote regional balanced development can continue to maintain the status of the international direct investment hot spots. Economic globalization has changed the pattern of enterprises competition, and the importance of the allocation of production resources in the international context is more obvious. In order to attract direct investment, many countries have also adopted a positive promotion measures, providing a high standard of treatment and legal protection. Simple policy incentives and low cost of production are not enough to attract investment, relatively speaking, the investment environment is more attractive. Therefore, China should focus on how to ensure and improve the efficiency of the conditions required to ensure and improve the efficiency of investors. From the location choice of foreign enterprise investment, human capital is one of the important factors to attract FDI, strengthening education and training to improve the local human capital stock, not only can attract more foreign investment, but also transfer the foreign capital flows from labor intensive industry to high and new technology industry, thus to attract more Multi-National Corporation to set up research and development centers in China. Industrial agglomeration area is also the main investment of foreign investors, therefore, the local government should implement the cluster strategy to encourage the development of dominant industries and leading industries and build effective infrastructure and related supporting measures around these industries to form industrial clusters. In addition, the protection of intellectual property rights and a good legal environment has a long-term significance to attract foreign investment, so strengthening the protection of intellectual property rights can attract Multi-National Corporation to invest, especially high-tech investors.

\section{References}

[1] Xiao Guangen. International direct investment location choice theory of new trend and development of the Asia Pacific Economic [J]. Asia-pacific Economic Review, 2009,02:10-14.

[2] Wang Wei, Li Feng. Analysis of new trends and tendencies of international direct investment -A Concurrent Discussion of influence of China [J]. Jiangsu social science, 2009,05:78-83.

[3] Cao Bin, Xu Guoqing. Trend and theory of international trade and international direct investment integration [J]. China trade, 2010,10:165-166.

[4] Wang Xiangyang. The current situation and development trend of international direct investment [J]. Modern marketing (School Edition), 2013,09:14. 